\begin{tabular}{|l}
\hline JURNAL \\
JURNAL \\
Pendidikan Dasar dan Keguruan \\
Volume 4, No. 1, 2020 \\
ISSN (print) : $2527-578$ X \\
ISSN (Print) $: 2715-6818$ \\
Homepage $\quad:$ http://journal.iaimsinjai.ac.id/index.php/JPDK \\
\hline
\end{tabular}

\title{
PENGARUH MEA TERHADAP SISTEM PERDAGANGAN INDONESIA SEBAGAI BAHAN AJAR IPS SD DI KELAS TINGGI
}

\author{
Izzatul Afidah ${ }^{\mathbf{1}}$, Irma Pritiningtiyas ${ }^{2}$, Depict Pristine $\mathbf{A d i}^{3}$ \\ ${ }^{1}$ IAIN Jember, Jl.Mataram No. 1 Karang Mluwo Mangli, Jember \\ ${ }^{2}$ IAIN Jember, Jl.Mataram No. 1 Karang Mluwo Mangli, Jember \\ 3. IAIN Jember, Jl.Mataram No. 1 Karang Mluwo Mangli, Jember \\ izzaafidah04@gmail.com, Tlp 089683891937
}

\begin{abstract}
Abstrak.
Tujuan dari penelitian ini yaitu untuk mendeskripsikan tentang pengaruh MEA terhadap sistem perdagangan Indonesia sebagai bahan ajar IPS SD di kelas tinggi sebagai salah satu contoh bahan ajar dalam pembelajaran IPS. Pengaruh MEA terhadap sistem perdagangan Indonesia sebagai bahan ajar IPS SD di kelas tinggi. Dalam proses pembelajaran kasus tersebut dapat membantu siswa di kelas tinggi, terutama pada materi kerjasama ekonomi internasional, kerjasama ekonomi internasioanl adalah hubungan yang dilakukan oleh suatu negara dengan negara lain melalui kegiatan ekspor dan impor. Metode yang digunakan dalam penelitian ini adalah metode kepustakaan dengan penyajian secara deskriptif dan analisis secara kualitatif dengan cara meneliti bahan-bahan kepustakaan seperti buku, jurnal, dan berita di internet, majalah, artikel, dan karya ilmiah lainnya yang di kutip di dalam proposal. Berdasarkan hasil pembahasan dapat disimpulkan bahwa kasus ini dapat di jadikan sebagai bahan ajar IPS untuk memberikan pemahaman kepada siswa dalam materi kerjasama ekonomi internasional. Sehingga anak faham dengan adanya kerja sama ekonomi internasional yaitu MEA bisa meningkatkan sistem perdagangan di Indonesia.
\end{abstract}

Kata Kunci: Multikultural Pengaruh MEA, Sistem Perdagangan, Bahan Ajar IPS, SD Kelas Tinggi

\begin{abstract}
The purpose of this study is to describe the effect of the AEC on the Indonesian trade system as social studies elementary school teaching materials in the high class as one example of teaching mateials in social studies learning. The effect of the AEC on the Indonesian trading system as a social studies teaching material for high school student. In the process of learning such cases can help students in high class, especially in the material of international economic cooperation, international economic cooperation is a relationship made by on country with another country through export and import activities. The method used in this research is the method of literature by presenting descriptively and analyzing qualitatively by examining library materials such as books, journals and news on the internet, magazines, articles, and other scientific works cited in proposals. Based on the results of the discussion it can be concluded that this case can be made as social studies teaching material to provide understanding to students in international economic cooperative material. So that children understand with the existence of international economic cooperative namely MEA can improve the trading system in Indonesian
\end{abstract}

Keywords: Effect of MEA, Trading System, Social Sciences Teaching Materials, High School Grade 


\section{Pendahuluan}

Masyarakat Ekonomi ASEAN (MEA) merupakan organisasi negara-negara di Asia Tenggara yang dikenal dengan istilah Asian Nations (ASEAN) yang didirikan pada tanggal 8 Agustus 1967 yang beranggotakan lima negara antara lain Indonesia, Malaysia, Singapura, Filipina dan Thailand dan bertempat tinggal di Jakarta. Asosiasi ini didikan dalam rangka kerjasama di bidang ekonomi, sosial, budaya, teknik, pendidikan,dan bidang lainnya seperti untuk menciptakan keamanan dan kesetabilan regional. Ketika melebihi dari 50 tahun berkipra, asosiasi tersebut mengalami perkembangan yang sangat signifikan, sehingga bertambahlah keanggotaanya menjadi 10 dengan masuknya Brunei Darussalam, Kamboja, Laos, Myamar dan Vietnam cita-cita ASEAN menjadi kesatuan wilayah ekonomi sudah di rancang sejak tahun 1977 dengan didirikannya ASEAN dan dimulailah ASEAN free trade area pada tahun 1992 (Asmara Sudomo, 2018:1).

Dalam bidang ekonomi secara bersama-sama pada tahun 2014 ASEAN tercatat sebagai urutan ketiga terbesar di Asia dan urutan ketujuh terbesar didunia. Dalam upayah menggapai pilar pada urutan yang pertama yaitu mendirikan pasar tunggal dan dasar produksi yang dilaksanakan oleh semua negera anggota ASEAN dengan mengadakan berbagai kompromi yang dikenal dengan istilah ASEAN Trade In Goods antara lain:

a. Dalam bidang perdagangan barang

b. Dalam bidang jasa

c. Dalam bidang penanaman modal atau infestasi

d. Dalam bidang ketentuan asal barang

e. Dalam bidang prosedur pabean

f. Dalam bidang standar dan kesesuaian

g. Dalam bidang fasilitas perjalanan di asean

h. Perpindahan pelaku usaha atau tenaga ahli profesional tenaga terampil dan orang berbakat

i. Peningkatkan perdagangan dan penanaman modal

j. Statistik perdagangan

k. Hak kekayaan intelektual

1. Penggunaan tenaga kerja kontrak dan industri pelengkap. (AEC Center, 2015:2)

Masyarakat Ekonomi ASEAN (MEA) / ASEAN Economic Comunity (AEC) adalah suatu bentuk integritas ekonomi dimana hal itu adalah merupakan jadwal pertama negara ASEAN 2020 yang visinya dari ASEAN yaitu aliran bebas barang (free flow of goods) pada tahun 2015 perdagangan barang dapat digunakan secara bebas dan tidak mengalami hambatan, baik tarif maupun non tarif. Kemudian pada tahun 2007 anggota MEA menetapkan untuk menyegerakan tercwujudnya masyarakat ekonomi ASEAN (MEA) / ASEAN Economic Community (AEC). ASEAN mempunyai misi untuk mewujudkan kalangan yang aman, makmur, damai, sentosa dan persaingan yang sehat untuk mencapai sistim perdagangan yang saling menguntungkan sehingga arus barang, jasa dan modal dapat berunifikasi di ASEAN. (Sjamsul Arifin dkk, 2008:71).

Indonesia menghadapi itikad yang berat untuk memandang kemajuan perekonomian suatu negara, dimana unifikasi ekonomi ASEAN dihadapkan dengan tantangan yang sangat besar dikarenakan negara angogta ASEAN mempunyai sistem perekonomi, tingkat pembangunan, dan pendapatan perkapita yang berbeda dan homogen. Oleh karena itu pemerintah selalu berusaha meningkatkan volume perdagangan baik dalam ASEAN maupun di luar ASEAN, demi terciptanya perekonomian Indonesia secara global. Tapi pada kenyataanya Indonesia memiliki banyak potensi dan sumber daya yang tidak di manfaatkan oleh negara-negara ASEAN dan juga pula ada yang menggunakan untuk keperluan ekonomi nasional kemudian hubungan Indonesia di bidang ekonomi dan perdagangan bersama ASEAN tidak mempunyai daya saing.

Dengan melakukan perdagangan bebas di wilayah Asia Tenggara, MEA sangat mempunyai peran penting dalam negara anggota serta tidak lepas dari pengaruh positif. Walaupun belum terasa pengaruh positifnya tetapi diharapkan mempunyai manfaat yang besar dari MEA dan akan terasa pada 


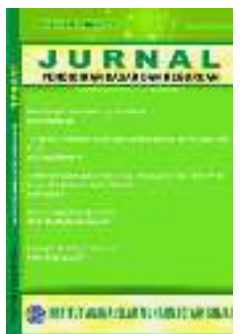

JURNAL

Pendidikan Dasar dan Keguruan

Volume 4, No. 1, 2020

ISSN (print) : 2527-578X

ISSN (Print) : :2715-6818

Homepage $\quad:$ : http://journal.iaimsinjai.ac.id/index.php/JPDK

tahun-tahun berikutnya. Keuntungan manfaat ekonomi ASEAN (MEA) akan memotivasi arus penanaman modal dari luar negeri yang akan masuk ke dalam negeri sehingga akan menciptakan multipeler effect untuk memudahkan dalam pendirian kerjasama antar perusahaan yang satu dengan perusahaan lainnya pada wilayah ASEAN. Sehingga masuknya bahan produksi ke negara-negara lain akan lebih mudah. MEA mengasih peluang pada negara-negara ASEAN agar meningkatkan percepatan perpindahan sumber daya manusia dan modal yang merupakan salah satu faktor produksi yang sangat penting di dalam bidang teknologi MEA mengadapkan transfer teknologi dari negara maju kepada negara yang berkembang di wilayah Asia tenggara.

Selain mempunyai dampak positif, MEA memiliki 4 hal untuk memusatkan dan menjadikan suatu kesempatan yang baik bagi Indonesia negara yang berada di wilayah Asia Tenggara akan dijadikan wilayah kesatuan pasar dan basis produksi, MEA didirikan sebagai wilayah ekonomi dengan tingkat daya saing yang tinggi untuk melakukan kebijakan meliputi Competition Policy,customer protection, intellectual property ringht, taxation, dan ecommerce dari ketiga MEA tersebut dijadikan kawasan atau wilayah yang memiliki perkembangan ekonomi yang rata dengan menomer satukan pada UKM, MEA terintergasikan secara penuh kepada ekonomi global.(Umar Congge, 2015:97)

Ekonomi sekarang ini menjadi salah satu prioritas utama dalam politik luar negeri indonesia terutama sejak adanya pemerintahan yang terakhir (era presiden joko widodo). Presiden joko widodo menyampaikan bahwa seluruh duta besar Republik Indonesia wajib berperan sebagai salesman, dengan ketentuan sebagai berikut 90 persen aspek ekonomi dan 10 persen untuk aspek politik (Susilo, 2014). Presiden Indonesia mengiginkan akses pasar-pasar luar negeri lebih di perluas lagi sehingga dapat meningkatkan volume ekspor di Indonesia dengan berkembangnya tingkat ekspor di indonesia, dapat membantu meningkatkan perekonomian dalam negeri terutama untuk mensejahterakan seluruh rakyat Indonesia. Secara ekonomi dengan adanya perdagangan internasional akan berpengaruh terhadap aspek konsumsi, produksi, dan distribusi pendapatan (Sjahril, 2013)

Di dalam pembelajaran kasus sistem perdagangan di Indonesia merupakan suatu contoh dari bahan ajar IPS materi kerjasama ekonomi Internasional. Bahan ajar adalah sarana atau alat pembelajaran yang memuat materi, metode, batasan-batasan dan cara mengevaluasi yang di rancang secara sistematis dan menarik untuk mencapai tujuan yang diharapkan. Karena dengan kasus sistem perdagangan Indonesia yang melibatkan kerja sama ekonomi Internasional jika dikaitkan dengan bahan ajar maka akan memudahkan siswa untuk memahami materi tersebut. Bahan ajar dalam pembelajaran merupakan materi yang digunakan oleh guru saat proses pembelajaran untuk membantu pendidik dalam memberikan pemahaman terhadap peserta didik terkait dengan materi yang dipelajari. Sehingga tujuan dari proses pembelajaran ini bisa tercapai dengan baik. Untuk menciptakan suasana belajar yang menyenangkan maka peran pendidik harus menggunakan suatu model pembelajaran seperti model jigsaw, Problem Based learning sehingga proses pembelajaran tidak terkesan monoton tetapi menyenangkan (Widodo dan Jasmani Dalam Lestari, 2013:1).

Dari latar belakang masalah yang ada, penulis merumuskan rumusan masalah dalam penelitian ini adalah bagaimana pengaruh MEA terhadap sistem perdagangan Indonesia sebagai bahan ajar IPS SD di kelas tinggi? Dengan tujuan penulisan dalam jurnal ini sebagai berikut: untuk mengetahui pengaruh MEA terhadap sistem perdagangan Indonesia sebagai bahan ajar IPS SD di kelas tinggi.

\section{Metode}

Dalam metode penelitian ini menggunakan jenis kajian kepustakaan. Kajian kepustakaan adalah pengkajian yang digunakan untuk pengumpulan data yang bersifat kepustakaan atau telaah yang digunakan untuk memecahkan suatu masalah yang tertumpu pada penelaahan kritis dan mendalam terhadap bahan-bahan pustaka yang relevan. Adapaun berbagai sumber yang dipakai yaitu buku-buku teks, jurnal, internet dan sumber-sumber lain yang relevan. (Nazir, 2005:93) 


\section{Hasil dan Pembahasan}

Hasil dari kajian kepustakaan yang diperoleh sebagai berikut: Pengaruh MEA terhadap sistem perdagangan membawa dampak yang positif, ini terbukti dengan adanya MEA maka negara-negara ASEAN mendapat kontribusi dalam masing-masing sektor prioritas, yakni Indonesia (Agro dan priklanan), Philipina (elektonik), Singapura (e-ASEAN dan kesehatan), Thailand (penerbangan dan Turis). Dengan kerjasama yang dilakukan oleh ASEAN produk-produk industri semakin meningkat setiap tahunnya. Penerapan bahan ajar IPS materi kerjasama ekonomi Internasional sebagai salah satu contoh kasus yang terjadi. MEA merupakan suatu contoh dari wujud kerjasama Internasional. MEA adalah suatu sistem pasar bebas antara satu negara anggota ASEAN yang tidak melakukan pungutan pajak atau bea cukai dan kebebasan suatu negara untuk memasukkan barangnya ke negara lain. (Widhiya Ninsiana, 2016:126)

Pengaruh MEA terhadap sistem perdagangan Indonesia dalam kasus ini mengkaitkan dengan materi pembelajaran di kelas tinggi sehingga siswa lebih mampu memahami materi tentang hubungan kerja sama Internasional. Pertama yang akan di bahas dalam materi ini adalah ASEAN (Association of Southeast Asian Nations) merupakan satu tempat wadah persekutuan antara Negara-negara di kawasan Asian Tenggara. ASEAN didirikan pada tanggal 8 Agustus 1967 di Bangkok oleh lima Negara dengan masing-masing menteri luar negeri, yakni: Adam Malik dari Indonesia, Tun Abdul Rajakdari Malaysia, Narcisco R. Ramos dari Filipina, S. Rajaratnam dari Singapura dan Thanat Khomandari Thailand melalui penandatanganan suatu deklarasi, atau yang biasa disebut dengan Deklarasi Bangkok. Kemudian Negara-negara sekawan lainnya juga ikut bergabung, yakni: Brunei Darussalam (bergabung pada tanggal 8 Januari 1984), Vietnam (bergabung pada tanggal 28 Juli 1995), Laosdan Myanmar (bergabung pada tanggal 23 Juli 1997), dan Kamboja (bergabung pada tanggal 30 April 1999), sehingga jumlah Negara anggota ASEAN sampai sekarang berjumlah sepuluh Negara (Mutiara Pratiwi, 2015:297).

Masyarakat Ekonomi ASEAN (MEA) merupakan bentuk integritas ekonomi ASEAN dalam artian adanya sistem perdagangan bebas antara Negara-negara ASEAN, Indonesia dan 9 anggota ASEAN lainnya (Malaysia, Philipina, Singapura, Thailand, Brunnai Darusslam, Vietnam, Laos, Myanmar, dan Kamboja). Telah menyepakati perjanjian masyarakat ekonomi ASEAN (MEA) atau Asean Economic Community (AEC) (Widhiya Ninsiana, 2016:125).

Tujuan dibentuknya ASEAN yang tercantum dalam deklarasi bangkok antara lain 1) mempercepat pertumbuhan ekonomi, untuk memajukan sosial serta pengembangan kebudayaan dikawasan ini melalui usaha bersama dalam semangat kesamaan dan persahabatan untuk menuju sebuah masyarakat bangsa di Asia Tenggara yang sejahtera dan damai 2) meningkatkan perdamaian dan stabilitas regional dengan keadilan dan ketertiban hukum di dalam sebuah hubungan antara negara di kawasan serta mematuhi semua prinsip piagam perserikatan bangsa-bangsa 3) meningkatkan kerjasama yang secara aktif yang saling membantu dalam sebuah masalah yang menjadi kepentingan bersama terutama dibidang ekonomi sosial teknik, ilmu pengetahuan dan atministrasi 4) saling memberi bantuan dalam bentuk sarana-sarana pelatihan dan penelitian dalam bidang pendidikan profesi teknik dan administrasi 5) bekerjasama secara lebih efektif untuk meningkatkan pemanfaatan pertanian industri mereka, memperluas perdagangan dan pengkajian masalah-masalah komoditi internasional, memperbaiki sarana-sarana pengangkutan dan kmunikasi serta meningkatkan cara hidup rakyat 6) memajukan pengkajian mengenai asia tenggara 7) memelihara kerjasama yang erat dan berguna dengan berbagai organisasi internasional dan regional 


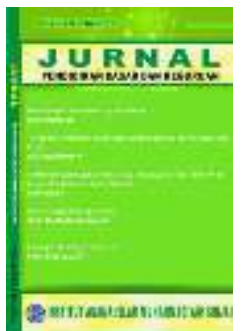

JURNAL

Pendidikan Dasar dan Keguruan

Volume 4, No. 1, 2020

ISSN (print) : 2527-578X

ISSN (Print) : 2715-6818

Homepage $\quad:$ : http://journal.iaimsinjai.ac.id/index.php/JPDK

yang mempunyai tujuan yang sama dan untuk menjaga semua kemungkinan untuk saling bekerja sama secara erat diantara mereka. (Maya Sari, 2015)

Beberapa prinsip utama dalam kerjasama ASEAN yaitu terdapat dalam suatu perjanjian (Triaty) yang mengatur prinsip dasar yang berhubungan antara sesama negara penandatanganan. Perjanjian ini bernama treaty of amity and cooperation (TAC) pada tahun 1976 yaitu 1) saling menghormati 2) kedaulatan dan kebebasan domestic tanpa campur tangan dari luar 3) non interference 4) penyelesaian perbedaan atau sengketa dengan cara damai 5) menghindari ancaman dan pengunaan kekuatan atau senjata. 6) kerjasama efektif antara anggota. Perjanjian TAC diatas dinyatakan bahwa kerjasama dan dialog politik serta keamanan haruslah ditujuhkan demi meningkatkan stabilitas dan perdamaian kawasan melalui suatu peningkatan kemajuan kawasan.

Tujuan pembentukan komunikasi ASEAN ini adalah untuk memacu terwujudnya masyarakat ekonomi ASEAN dan untuk merubah ASEAN menjadi daerah dengan perdagangan bebas yaitu berupa barang dan jasa, investasi, tenaga kerja terampil, serta aliran modal yang lebih terbuka. MEA berkerja sesuai dengan faham bebas, mengarah keluar, inklusif, dan mengarah pada pasar ekonomi yang tatap dengan aturan multilateral serta ketaatan terhadap sistem untuk kepatuhan dan pelaksanaan tanggung jawab ekonomi yang efektif dan efisien berdasarkan aturan.Hal ini sesuai dengan tujuan akhir integrasi ekonomi seperti yang dicantumkan dalam ASEAN vision 2020. (Widhiya Ninsiana, 2016:125)

Proses menuju kesepakatan MEA dimulai pada konferensi tingkat tinggi (KTT) ASEAN kedua pada tanggal 15 Desember 1997 di kuala lumpur, Malaysia dengan persetujuan sebuah visi ASEAN 2020 yang akan mewujudkan kawasan ekonomi ASEAN yang stabil, makmur dan memiliki daya saing yang sangat tinggi dengan ditandai oleh arus lalu lintas barang, jasa-jasa dan investasi atau penanaman modal yang bebas, arus lalu lintas modal yang sangat bebas, pembangunan ekonomi yang merata dan mengurangi kemiskinan serta kesenjangan sosial ekonomi, mempercepat liberalisai perdagangan di bidang jasa, dan meningkatkan pergerakan tenaga profesional dan jasa yang lainnya secara bebas di dalam kawasan. Kemudian pada KTT ke 6 ASEAN pada tanggal 6 Desember 1998 di hanoi, Vietnam para pemimpin ASEAN mengesahkan rencana aksi hanoi yang juga merupakan suatu langkah pertama untuk merealisasikan suatu tujuan visi 2020 ASEAN. Rencana ini mempunyai pembaasan waktu yaitu 6 tahun dari mulai tahun 1999 sampai 2004. Selanjutnya pada KTT ke 7 ASEAN pada tanggal 5 November 2001 di bandar Seri Begawan, Brunei Dasrusalam sepakat dibentuknya RIA sedangkan pada pertemuan ke 34 pada tanggal 12 September 2002 di Bandar seri begawan, Brunai Darusallam dan beberapa mentri ekonomi ASEAN mengesahkan RIA tersebut adapun rencana aksi antara lain 1) mengembangkan dan menggunakan pendekatan alternatif untuk liberalisasi 2) mengupayakan penerapan kerangka regulasi yang sesuai 3) menghapuskan semua halangan yang menghambat pergerakan bebas perdagangan jasa di kawasan ASEAN 4) menyelesaikan kesepakatan pengakuan timbal balik untuk bidang jasa profesional.

Indonesia sudah melakukan retifikasi piagam ASEAN pada tanggal 6 November 2008 dalam bentuk UUD No 38 tahun 2008 tentang pengesahan carter of ther asusiassion of southeast asean nation (piagam perhimpunan bangsa-bangsa asia tenggara). Perkembangan kondisi perdagangan Internasional Indonesia terhadap MEA 2015 ekspor dan impor berdasarkan catatan dari badan pusat statistik (BPS) ada beberapa faktor yang membuat nilai ekspor Indonesia untuk intra dan ekstra tahun 2013 mengalami penurunan hingga senilai 3,92\% dari tahun 2020 dimana hal ini dikarenakan oleh berkurangnya ekspor migas yaitu dari tahun 2012 sebesar 19,46\% menjadi 17,87\% ditahun 2013 akan tetapi untuk ekspor non migas mengalami peningkatan dari tahun 2012 ke tahun 2013 contohnya 
minyak nabati dan produk industri sebesar $61,11 \%$ menjadi $61,91 \%$ kemudian produk pertambangan 16,50\% menjadi $17.08 \%$ dan produk pertanian $2,93 \%$ menjadi $3,14 \%$ yang inilah menjadi sebuah sektor yang telah mampu menyelamatkan nilai ekspor di Indonesia. Sementara itu untuk nilai impor Indonesia intra maupun ekstra tahun 2013 juga mengalami suatu penurunan senilai 2,64\% dibandingkan dengan nilai impor tahun 2012 hal tersebut dikarenakan oleh nilai impor non migas yang mengalami penurunan senilai 5,20 dan dapat meningkatkan nilai impor migas senilai 6,30\% peningkatan impor migas tersebut disebabkan bertambahnya minyak mentah dan gas masing-masing senilai $25,76 \%$ dan $1,02 \%$ semetara impor untuk hasil minyak mengalami penurunan senilai $0,39 \%$.

Ekonomi ASEAN membentuk ASEAN sebagai pasar dan basis produksi tunggal. Masyarakat ASEAN akan menjadi dinamis dan kompetitif dalam segala hal. Dan dengan pembentukan MEA di kawasan ASEAN semakin memperkuat kerjasama masyarakat ASEAN itu sendiri. Adapun bentuk kerjasama MEA yakni:

a. Pengembangan sumber daya manusia dan peningkatan kapasitas

b. Pengakuan kualifikasi professional

c. Konsultasi lebih dekat dengan kebijakan makro ekonomi keuangan

d. Langkah-langkah pembiayaan peragangan

e. Meningkatkan infrastruktur

f. Pengembangan transaksi elektronik melalui e-ASEAN

g. Mengintegrasikan industry di seluruh wilayah untuk mempromosikan sumber daerah

h. Meningkatkan keterlibatan sektor swasta untuk membangun masyarakat ekonomi ASEAN. (Widhiya Ninsiana, 2016:126)

Berdasarkan kerjasama di antara Negara-Negara ASEAN di atas, dapat disimpulkan kontribusi dalam masing-masing sektor prioritas, yakni Indonesia (agro dan periklanan), Philipina (elektronik), Singapura (e-ASEAN dan kesehatan), Thailand (penerbangan dan touris). (Jamal, 2010:14)

Kerjasama yang dilakukan ASEAN yitu melalui kerjasama ekonomi pada sektor industri yaitu termasuk salah satu sektor utama meliputi makan dan minuman, tekstil, kertas, batu bara, minyak serta gas bumi dan lain-lain tapi produk inilah yang harganya meningkat dari tahun ke tahun Kerjasama ASEAN ini tertuju pada terciptanya sarana produksi baru dalam rangka untuk mendorong perdagangan intra-ASEAN. Adapun dalam bentuk harga produk-produk industri yakni dapat dilihat bahwa dari tahun 2000-2011 total harga produk-produk industri semakin meningkat setiap tahunnya walaupun pada tahun 2003 mengalami penurunan (Mutiara Pratiwi, 2015:299).

Indonesia dalam menghadapi MEA masih diragukan sebagian masyarakat secara umum dengan melihat dampak positif dan negatif terhadap konsekuensi masuknya produk barang dan jasa secara bebas dan berbagai kemudahan yang harus dilakukan oleh pemerintah Indonesia. Dampak positif lainnya yaitu banyak infestor Indonesia yang dapat menambah ruang penanaman modal tidak ada batasan ruang antara negara anggota ASEAN dan dapat menarik infestasi dari pemodal-pemodal ASEAN. Selain dampak positif, MEA juga mempunyai dampak negatif yaitu adanya pasar secara bebas akan mengakibatkan tenaga kerja asing akan mudah masuk ke Indonesia dan bekerja akan mengakibatkan persaingan di bidang tenaga kerja. (Umar Congge, 2015:103)

Pada bagian perdagangan, MEA akan dijadikan peluang emas bagi Indonesia karena kendala perdagangan akan berkurang bahkan tidak ada kendala sama sekali, hal ini akan berpengaruh pada peningkatan ekspor yang akan meningkatkan Gross Domestic Product (GDP) Indonesia. 


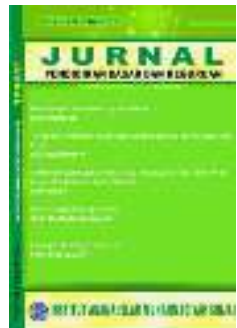

JURNAL

Pendidikan Dasar dan Keguruan

Volume 4, No. 1, 2020

ISSN (print) : 2527-578X

ISSN (Print) : :2715-6818

Homepage $\quad:$ : http://journal.iaimsinjai.ac.id/index.php/JPDK

Pada sisi lain, pembentukkan MEA membuka sejumlah peluang bagi Indonesia dalam meningkatkan sektor perekonomian Nasional maupun posisi strategis Indonesia baik dalam lingkup intra ASEAN maupun ekstra ASEAN. Untuk memastikan MEA berjalan sesuai dengan apa yang telah di rancang dan Indonesia dapat memperoleh keuntungan dari MEA, tentu saja salah satu hal yang penting dilakukan oleh Indonesia adalah dengan melakukan berbagai pembaharuan hukum yang lebih berorientasi pada jaminan dan kepastian hukum sesuai dengan yang diinginkan dalam peraturan perjanjian kerjasama bidang ekonomi ASEAN.

Menjelang MEA yang sudah semakin dekat, pemerintah Indonesia menginginkan dapat mempersiapkan langkah yang baik dalam segi tenaga kerja, segi infrastruktur dan segi industri untuk menghadapi persaingan dan perdagangan bebas dalam skala ASEAN. Kebijakan-kebijakan pada berbagai sektor yang dipakai oleh pemerintah jangan hanya berskala nasional (sentralistik) tapi juga harus bersifat desentralistik atau (otonom). Jika kebijakan yang dibuat pemerintah untuk menghadapi MEA yang bersifat sentralistik, maka akan terjadi ketimpangan dan ketidakseimbangan yang pada akhirnya menjadikan daerah semakin tertinggal dan tidak bisa bersaing yang pada akhirnya akan menjadi hambatan secara nasional (Umar Congge, 2015:103).

Indonesia dengan jumlah penduduk yang sangat besar merupakan potensi bagi perusahaan untuk memasarkan produk dan jasa, serta potensi pasar tenaga kerja yang melimpah dapat menjadikan dampak yang positif dari adanya MEA. Investasi dalam negeri berpotensi akan mengalami peningkatan dan juga akan menambah jumlah lapangan pekerjaan di dalam negeri bertambahnya lapangan perkerjaan di Indonesia dapat juga menambah kesempatan kerja bagi tenaga kerja bagi tenaga kerja Indonesia dampak positif yang lain yaitu penduduk indonesia bisa mencari pekerjaan di luar negeri dengan aturan yang lebih lunak ( Erliz Rifa $2015: 2$ ).

Dengan adanya pasar bebas Indonesia terkena dampak positif dan dampak negatif dari basar bebas tersebut dampak positifnya indonesia dapat berdagang dengan mudah keluar negeri sehingga bisa meningkatkan defisa negara derta memberi kemuduhan bagi ekspotir barang ke luar negeri sehingga dengan adanya pasar bebas ini dapat memacu pengusaha da perusahaan untuk memproduksi lebih banyak barang. Dengan adanya perluasan pasar dapat menambah modal dari luar negeri ke indonesia sedangkan dampak negatifnya yaitu ketika indonesia belum siap dalam pasar bebas sehingga indonesia kalah dalam persaingan terutama dalam hal tenaga kerja (Chirstofora,2014: 485)

Hal itu bisa menjadi ancaman bagi Indonesia terutama dalam jumlah tenaga kerja yang relatif lebih sedikit, dampak dari MEA salah satunya adalah akan banyaknya jumlahnya tenaga kerja asing (TNA) yang masuk ke Indonesia namun banyak jumlah TNA yang masuk ke Indonesia lebih sedikit dibandingkan dengan tenaga kerja indonesia yang keluar negeri, tenaga kerja asing yang bekerja di Indonesia paling banyak bukan dari negara asean-asean melainkan berasal dari rakyat tiyongkok, jepang dan india (Stanislaus, 2016:21)

Pemerintah telah membuat keputusan yaitu tentang keputusan mentri tenaga kerja dan trasmigrasi nomer 40 tahun 2012 tentang jabatan-jabatan tertentu yang dilarang ditempati oleh tenaga kerja asing sebagai upaya bentuk perlindungan dan penantisipasian globalisai di sektor jasa dan tenaga kerjaan (Bagus:5). Untuk peningkatan jumlah tenaga kerja yang terampil dikawasan, anggotaanggota ASEAN melakukan kerjasama dalam bidang pendidikan. ASEAN university neet work (AOU) dibentuk pada bulan november 1995 dan telah melakukan banyak aktivitas di bidang akademi seperti diskusi, workshop, seminar study dan penelitian bersama di bidang-bidang yang menjadi prioritas ASEAN, program bea siswa pertukaran mahasiswa dan sebagainya (Bella, 2017:8) 


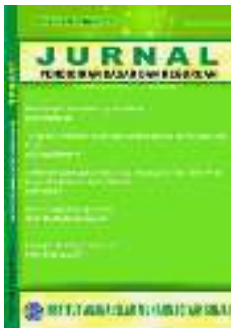

JURNAL

Pendidikan Dasar dan Keguruan

Volume 4, No. 1, 2020

ISSN (print) : 2527-578X

ISSN (Print) : :2715-6818

Homepage $\quad:$ : http://journal.iaimsinjai.ac.id/index.php/JPDK

Kegiatan pembelajar di kelas tinggi, keterlibatan pendidik dalam mengajar mengharuskan peserta didik dapat memahami seluruh materi yang diberikan saat pembelajaran berlangsung, untuk itu agar memudahkan pendidik memberi pemahaman kepada peserta didik maka pendidik perlu menggunakan bahan ajar salah satu contoh bahan ajar yaitu handout, handout adalah bahan ajar tentang materi yang diajarkan. Untuk melatih kompetensi peserta didik dalam beransumsi maka handout dibutuhkan oleh para pendidik seperti pada materi kerjasama Internasional. Sehingga dengan demikian peserta didik akan memiliki kemampuan berfikir kritis dalam memecahkan sebuah persoalan terutama dalam materi kerjasama Internasional.

Pendidik merupakan salah satu kunci keberhasilan suatu lembaga pendidikan, sebagai sales agent dari lembaga pendidikan mempunyai pengaruh terhadap kesan yang muncul dalam masyarakat baik atau tidaknya pendidik dalam memberikan pelayanan sehingga proses belajar akan mempegaruhi citra sebuah lembaga pendidikan. Sehubungan dengan hal tersebut sumber daya pendidik harus ditingkatkan baik melalui pendidikan ataupun pelatihan sehingga kemampuan profesionalnya dapat meningkat (Diarti, 2019:25). Untuk mengelola kelas tinggi yang efektif perlu diperhatikan hal-hal sebagai berikut kesepakatan bersama mengenai kontrak belajar selama berada di dalam kelas, infentarisasi kelompok murid bersifat informal bila kelompok ini membawa pengaruh yang negatif maka harus diarahkan ke hal yang positif, memberikan bimbingan kepada murid yang apatis, masa bodoha atau bersikap bermusuhan sehingga hal tersebut bisa menciptakan kondisi yang diharapkan oleh seorang pendidik didalam menyampaikan materi yang diajarkan.

Guru adalah pendidik yang hanya dijumpai anak setelah memasuki suatu lingkungan pendidikan formal atau sekolah. Dengan kata lain guru adalah merupakan pendidikan berikutnya setelah anak mendapatkan pendidikan dari orang tuanya oleh sebab itu pendidikan tersebut harus berkelanjutan agar diperoleh hasil yang semaksimal mungkin, terutama dalam hal pembinaan masalah kecerdasan emosional dan spiritual bagi anak didik, sehingga akan nampak bahwa pendidik memiliki peran yang sangat besar terhadap pembinaan kecerdasan emosional dan spiritual peserta didik. Oleh karena itu fungsi guru sebagai tenaga pengajar menuangkan ilmu pengetahuan dalam otak peserta didik, juga diharapkan agar pendidik dapat membentuk jiwa keagamaan peserta didik dengan tetap berpegang kepada kode etik guru, profesinya serta kepribadiannya agar dapat diterima oleh peserta didik di kelas tinggi dalam segala hal seperti yang disampaikan oleh pendidik. Pendidik harus menyadari bahwa disamping mempunyai tangung jawab untuk proses belajar mengajar dalam membentuk intelektuallitas peserta didik, pendidi juga harus mempunyai peranan penuh dalam menanamkan pada peserta didik untuk memiliki sikap-sikap terpuji, jujur, kasih sayang, tolong menolong, bersahabat, silaturahmi, berkomunikasi dan saling mengigatkan sehingga hal ini sangat mempunyai peranan yang sangat besar didalam ketercapaian kompetensi belajar terutama pada materi IPS di kelas tinggi (Sudirman, 2019: 9).

\section{Simpulan}

Berdasarkan deskripsi mengenai pengaruh MEA terhadap sistem perdagangan Indonesia sebagai materi pembelajaran IPS SD di kelas tinggi dapat disimpulkan bahwa, dalam kasus ini dapat digunakan sebagai materi pembelajaran IPS untuk memberikan pemahaman kepada siswa dalam materi kerjasama internasional atau kegiatan ekspor dan impor.untuk itu pendidik harus membuat bahan ajar berupa handout yang berisi materi yang di ajarkan sehingga peserta didik akan memiliki kemmpuan berfikir dalam memecahkan sebuah persoalan dalam materi kerjasama Internasional. Dengan MEA sistem perdagangan di Indonesia menghadapi kemajuan yang semakin pesat, sebab perkembangan ekspor berpengaruh positif terhadap GDP Indonesia. Hal ini karena MEA menerapkan 


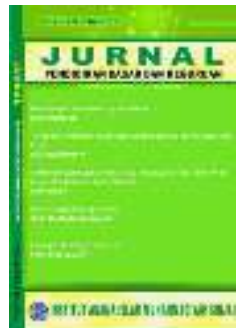

JURNAL

Pendidikan Dasar dan Keguruan

Volume 4, No. 1, 2020

ISSN (print) : 2527-578X

ISSN (Print) : :2715-6818

Homepage $\quad:$ : http://journal.iaimsinjai.ac.id/index.php/JPDK

sistem perdagangan bebas, dan dampak positifnya penanaman modal di Indonesia dapat memperluas lingkup penanaman modalnya dan dapat menarik investasi lainnya dari para pemodal ASEAN.

\section{Daftar Pustaka}

Amalia, Bella. (2017) Dampak ASEAN Economic Community (AEC) Terhadap Tenaga Kerja Indonesia Di Singapura. JOM FISIP, 4, 1-14.

Apresian, Stanislaus Risadi (2016) Arus Bebas Tenaga Kerja Dlam Era Masyarakat Ekonomi ASEAN: Ancaman bagi Indonesia? Indonesian Perspective, 2, 15-29

Arifin, Sjamsul dkk. (2008). Masyarakat Ekonomi ASEAN (MEA): Memperkuat Sinergi ASEAN di Tengah Kompetisi Global. (Jakarta: Gramedia).

Center, AEC. (2015). Jurnal Single Market dan Production Base.

Congge, Umar. (2015). Masyarakat Ekonomi ASEAN (MEA) Harapan dan Tantangan Dalam Perekonomian Bangsa. Jurnal Seminar Nasional "Revolusi Mental dan Kemandirian Bangsa Melalui Pendidikan Ilmu-ilmu Sosial dalam Menghadapi MEA 2015". Kerjasama; Fakultas Ilmu Sosial Universitas Negeri Makassar dan Himpunan Sarjana Pendidikan Ilmu-ilmu Sosial Indonesia. (Makassar, 28-29 Nopember 2015) diakses pada tanggal 18 Maret 2020.

Jamal. 2010. Globalization dan Terrorism; The Migration Off Dreams and Nightmars. (Oxford; Rowman and Littlefield).

Maya Sari. (2015). 7 Tujuan ASEAN (Association Off Southheast Asian Nation).diakses dari http://guruppkn.com /tujuan-ASEAN. Diakses pada tanggal 18 April 2020 pukul 15.47

Ninsiana, Widhiya. (2016). Revolusi Mental Bidang Pendidikan Pada Masyarakat Ekonomi ASEAN (MEA). Jurnal TARBAWIYAH 13(1), 125. Diakses dari http://ejournal.metrouniv.ac.id/index.php/tarbawiyah/article/download/490/290. Diakses pada tanggal 17 april pukul 11.30

Ningsih Andra Diarti. (2019). Guru Sebagai Manajer Kelas. Jurnal Pendidikan Dasar dan Keguruan. Vol. 1 No. 1. . IAI Muhammadiyah Sinjai

P Sudirman. 2019. Peranan Pendidikan Dalam Menumbuhkan Kecerdasan Emosional Anak. Jurnal Pendidikan Dasar dan Keguruan. Vol. 1, No. 1. IAI Muhammadiyah Sinjai.

Prasetyo, Bagus. Menilik Kesiapan Dunia Ketenagakerjaan Indonesia Menghadapi MEA. Jurnal RechtsVinding media Pembinaan Hukum Nasional. 1-7.

Pratiwi, Mutiara. (2015). Pengaruh MEA 2015 Terhadap Integritas Pada Sistem Perdagangan di Indonesia. Jurnal Ekonomi dan Keuangan 3(4). Terapan, Edisi Agustus, Vol. 6 No. 2 hal 86-97

Pratiwi, Eliz Nindi dan Rifa Atun Mahmudah. (2012) Peningkatan Daya Saing Tenaga Kerja Indonesia Melalui Korelasi Input Penunjang Tenaga Kerja Dalam Menghadapi MEA 2015. Economic Development Analysis Journal 2, 2, 1-7

Sjahril, S. (2013), “ Simulasi Dampak Liberalisasi Perdagangan Bilateral RI-China terhadap Perekonomian Indonesia: Sebuah Pendekatan SMART Model," Jurnal Ekonomi Kuantitatif.

Sudomo, Asmara. (2018). Gaung Masyarakat Eonomi ASEAN (MEA) di Lingkungan Profesi Sekretaris.

Susilo, D. (2014), "Dubes menjadi Salesman" Opini Jawa Pos, 24 Juni. Dapat diakses pada situs: http://www.jawapos.com/baca/artikel/3255/Dubes-Menjadi-Salesman diakses pada tanggal 28 April pukul 19.00.

Tirtawinata, Christofora Megawati (2014) Karakter Yang Diperlukan Dunia Kerja Dalam Menghadapi Pasar Bebas ASEAN 2015. Humaniora 5, 1, 483-493.

Widodo, dkk. (2013). Pegertian Bahan Ajar Menurut Para Cenekiawan. Diakses dari htttp://www.silabus.web.id/pengertian-bahan-ajar-menurut-para-cendekiawan/. Diakses pada tanggal 18 April 2020 pukul 15.12 